\title{
STUDIES ON THE EFFECT OF SHEEP POX VACCINE ON THE IMMUNE RESPONSE OF SHEEP VACCINATED WITH PNEUMO-4 VACCINE
}

\author{
Amal A. Fotouh"; Nermeen G. Shafik"; Effat L. El-Sayed";and Wassel, M.S." \\ Veterinary Serum and Vaccine Research Institute, Abbasia, Cairo \\ " Central Laboratory for Evaluation of Veterinary Biologics, Abbasia, Cairo
}

\begin{abstract}
Convincing seroimmunological studies were conducted to explore the influence of sheep pox vaccine on the immune response to pneumo-4 vaccine in vaccinated sheep, when it is administrated before, after and simultaneously. The experiment was conducted on eighteen susceptible sheep divided into 6 equal groups. Groups 1 and 5 were vaccinated with pneumo-4 vaccine and sheep pox vaccine respectively regarded as control vaccinated groups. Sheep pox vaccine was administered simultaneously with pneumo-4 in Group (2), before and after pneumo4 vaccine in groups (3 and 4) respectively. The sixth group being left as a non-vaccinated control. The developed antibodies against different antigens incorporated in the used vaccines were monitored by using both serum neutralization test (SNT) and ELISA. The results showed that when sheep pox was administered one-week before vaccination with pneumo-4, the highest antibody titres were developed followed by these induced by simultaneous vaccination in group (2). So, the result explores the immunopotentiating effect of sheep pox vaccine on the immune response of sheep to pneumo-4 vaccine specially when it is administered one week before the other vaccine.
\end{abstract}

Key Word: sheep pox vaccine, immune response, pneumo-4 vaccine. 


\section{INTRODUCTION}

Bovine respiratory cyncytial (BRSV), parainfluenza-3 (PI-3), infectious bovine rhinotracheitis (IBR) and bovine viral diarrhoea (BVD) viruses have all been incriminated in the etiology of acute respiratory disease of economic importance in live stock (Durham and Hassard, 1990). They are causing serious losses not only deaths but also weight loss and insufficient feed conversion.

The previous studies proved the wide distribution of respiratory viruses in Egypt (El-Dobeigy et al., 1983, Baz et al., 1986 and Attia et al., 1999).

Inactivated vaccine against these viruses was commonly used for prophylaxis purposes inducing good results of protection against pneumoenteritis syndrome (Knezevic, et al. 1990 and Hussein, et al., 1996).

Sheep pox vaccine has proved to be immunopotentiator when used with other vaccines (Taha et al., 1991, Abeer, 1996 and Samir et al., 1999). Also, Abdel Samae, et al., (1994) found that sheep pox vaccine played an immunopotentiating role in production of antibodies against RVF virus in sheep. Hussein et al. (1996) recorded that sheep pox vaccine initiated the immune response of calves when vaccinated by triangler-4 vaccine, 21 days after their vaccination with sheep pox vaccine.

The aim of this work is to study the effect of sheep pox vaccine on the immune response of sheep vaccinated with pneumo-4 vaccine (including IBR, PI-3, BVD and BRSV) when it is administered before, simultaneously and after vaccination with pneumo-4 vaccine. 


\section{MATERIAL AND METHODS}

\section{Vaccines:}

\subsection{Pneumo-4 vaccine:}

Local combined inactivated vaccine containing bovine virus diarrhoea (BVD), infectious bovine rhinotracheitis (IBR), parainfluenza3 (PI-3) and bovine respiratory syncytial virus (BRSV) supplied by Rinderpest Like Disease Dept., Veterinary Serum and Vaccine Research Institute, Abbasia, Cairo. The used dose was 3ml/animal administered twice intramuscularly with two weeks apart.

\subsection{Sheep pox vaccine (SPV):}

Sheep pox vaccine (Kenyan strain) was supplied by Pox Vaccine Research Dept., Veterinary Serum and Vaccine Research Institute, Abbasia, Cairo. It has a titre of $10^{5.5} \mathrm{TCID}_{50} / \mathrm{ml}$ and the used field dose is $10^{3} \mathrm{TCID}_{50}$.

\section{Animals:}

Eighteen sheep of about 4-6 months old were used in this study. These sheep were tested and proven to be free from antibodies against pneumo- 4 and sheep pox viruses before vaccination. These animals were divided into 6 groups ( 3 animals/group) as follow:

\section{Group (1):}

The sheep were vaccinated with combined inactivated vaccine (Pneumo-4) only by injection with $3 \mathrm{ml}$ intramuscularly / each, twice, 2 weeks apart.

\section{Group (2):}

Vaccinated with both vaccines (Pneumo-4 and sheep pox vaccine) simultaneously. 
Group (3):

Vaccinated with sheep pox vaccine $(1 \mathrm{ml})$ intradermally, one week before vaccination with the first dose of pneumo-4 vaccine.

\section{Group (4):}

The sheep were vaccinated with sheep pox vaccine, one week after vaccination with the first dose of pneumo-4 vaccine.

\section{Group (5):}

The sheep were vaccinated with sheep pox vaccine only.

\section{Group (6):}

The sheep were kept unvaccinated used as control.

\section{Cell culture:}

\subsection{Madin Darby bovine kidney (MDBK) cell line:}

It was used for serum neutralization test of pneumo-4 viruses.

\subsection{Vero cell:}

African green monkey kidney (Vero) cell line was obtained from FADDL, Plum Island, USA and prepared according to Ozawa and Hazrati (1964). These cells were used in serum neutralization test of sheep pox.

\section{Seroconversion:}

\subsection{Serum Neutralization Test (SNT):}

It was done according to the OIE Manual (2000) for all serum samples collected before and after vaccination and calculated according to Reed and Muench (1938). 


\subsection{Indirect ELISA:}

It was performed according to Carn et al. (1994). The test was applied on the collected serum samples.

\section{Serum sampling:}

Blood samples were collected from all vaccinated and control sheep, then serum samples were collected after centrifugation and kept frozen at $-20^{\circ} \mathrm{C}$ till used.

The serum samples were collected at zero time (pre-vaccination) and at $2,3,4,6,8,12,16,20$ and 24 weeks post vaccination.

\section{RESULTS}

Table (1): Mean $\log _{10}$ BVD, IBR, PI-3 and BRSV serum neutralizing antibody titres in pneumo-4 vaccinated sheep

\begin{tabular}{|c|c|c|c|c|c|c|c|c|c|c|c|c|c|c|c|c|c|c|c|c|}
\hline \multirow{3}{*}{ WPV } & \multicolumn{20}{|c|}{$\log _{10}$ serum neutralizing antibody titre } \\
\hline & \multicolumn{4}{|c|}{ Group (1) } & \multicolumn{4}{|c|}{ Group (2) } & \multicolumn{4}{|c|}{\begin{tabular}{|l|} 
Group (3) \\
\end{tabular}} & \multicolumn{4}{|c|}{ Group (4) } & \multicolumn{4}{|c|}{ Group (6) } \\
\hline & 党 & 范 & 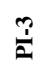 & $\frac{\vec{n}}{\infty}$ & 召 & 蒘 & $\stackrel{\ddot{1}}{\dot{\Delta}}$ & $\frac{\vec{n}}{\infty}$ & 盆 & 㕷 & $\stackrel{9}{\dot{I}}$ & $\frac{\overrightarrow{0}}{\frac{0}{0}}$ & $\overbrace{\infty}^{\circ}$ & 㕷 & $\stackrel{9}{\dot{I}}$ & $\frac{\overrightarrow{3}}{a n}$ & 空 & 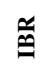 & $\stackrel{9}{2}$ & $\frac{3}{a}$ \\
\hline Pre & - & - & - & - & - & - & - & - & - & - & - & - & - & - & - & - & - & - & - & - \\
\hline 2 & 0.3 & 0.4 & 0.6 & 0.35 & 0.35 & 0.3 & 0.45 & 0.55 & 0.72 & 0.45 & 1.02 & 0.78 & 0.3 & 0.4 & 0.6 & 0.35 & - & - & - & - \\
\hline 3 & 1.05 & 1.2 & 1.35 & 0.9 & 1.2 & 1.4 & 1.2 & 1.2 & 1.5 & 1.45 & 1.2 & 1.26 & 1.35 & 1.2 & 1.2 & 0.96 & - & - & - & - \\
\hline 4 & 1.2 & 1.5 & 1.5 & 1.2 & 1.5 & 1.55 & 1.65 & 1.4 & 1.7 & 1.65 & 1.8 & 1.5 & \begin{tabular}{|l|}
1.2 \\
\end{tabular} & \begin{tabular}{|l|}
1.35 \\
\end{tabular} & 1.5 & \begin{tabular}{|l|}
1.2 \\
\end{tabular} & - & - & - & - \\
\hline 6 & 1.25 & 1.5 & 1.8 & 1.5 & 1.65 & 1.65 & 1.8 & 1.5 & 1.8 & \begin{tabular}{|l|}
1.75 \\
\end{tabular} & 2.1 & 1.95 & 1.5 & \begin{tabular}{|l|}
1.5 \\
\end{tabular} & 1.65 & 1.35 & - & - & - & - \\
\hline 8 & 1.45 & 1.5 & 1.65 & 1.2 & \begin{tabular}{|l|}
1.6 \\
\end{tabular} & \begin{tabular}{|l|}
1.7 \\
\end{tabular} & 1.8 & 1.45 & 1.8 & \begin{tabular}{|l|}
1.8 \\
\end{tabular} & 1.95 & 1.8 & 1.8 & \begin{tabular}{|l|}
1.65 \\
\end{tabular} & \begin{tabular}{|l|}
1.4 \\
\end{tabular} & 1.2 & - & - & - & - \\
\hline 12 & \begin{tabular}{|l|}
1.2 \\
\end{tabular} & 1.35 & 1.5 & 1.2 & \begin{tabular}{|l}
1.45 \\
\end{tabular} & 1.5 & 1.5 & 1.2 & 1.65 & 1.55 & $\begin{array}{l}1.8 \\
\end{array}$ & 1.5 & 1.5 & \begin{tabular}{|l|}
1.5 \\
\end{tabular} & 1.35 & 1.2 & - & - & - & - \\
\hline 16 & 1.3 & 1.2 & 1.35 & 1.05 & 1.35 & 1.2 & 1.2 & 1.1 & 1.5 & \begin{tabular}{|l|}
1.45 \\
\end{tabular} & 1.5 & 1.4 & 1.2 & \begin{tabular}{|l|}
1.35 \\
\end{tabular} & 1.2 & 1.1 & - & - & - & - \\
\hline 20 & 1.2 & 1.10 & 1.15 & 0.9 & \begin{tabular}{|l|}
1.2 \\
\end{tabular} & \begin{tabular}{|l|l}
1.05 \\
\end{tabular} & 0.96 & 0.9 & 1.35 & 1.2 & 1.2 & 1.2 & 1.05 & \begin{tabular}{|l|l|} 
\\
\end{tabular} & 1.05 & 0.9 & - & - & - & - \\
\hline 24 & \begin{tabular}{|l|}
0.8 \\
\end{tabular} & 0.9 & 0.9 & 0.6 & \begin{tabular}{|l|}
0.9 \\
\end{tabular} & 0.75 & \begin{tabular}{|l|l|}
0.6 \\
\end{tabular} & 0.6 & \begin{tabular}{|l|}
1.2 \\
\end{tabular} & \begin{tabular}{|l|}
0.96 \\
\end{tabular} & 1.05 & 0.78 & \begin{tabular}{|l|}
0.9 \\
\end{tabular} & \begin{tabular}{|l|}
0.6 \\
\end{tabular} & 0.75 & 0.6 & - & - & - & - \\
\hline
\end{tabular}

Pre.

Pre-vaccination

WPV Weeks Post Vaccination

Group (1): Sheep vaccinated with pneumo-4 vaccine only

Group (2): Sheep vaccinated with pneumo-4 and sheep pox vaccine simultaneously

Group (3): Sheep vaccinated with sheep pox, one week before vaccination with pneumo-4 vaccine

Group (4): Sheep vaccinated with sheep pox, one week after first dose of pneumo-4 vaccine

Group (6): Sheep unvaccinated control 
Amal A. Fotouh et al.,

Table (2): Mean ELISA (S/P ratio) in vaccinated sheep against BVD, IBR, PI3 and BRSV viruses (pneumo-4 vaccine)

\begin{tabular}{|c|c|c|c|c|c|c|c|c|c|c|c|c|c|c|c|c|c|c|c|c|}
\hline \multirow[b]{3}{*}{ WPV } & \multicolumn{20}{|c|}{$\mathrm{S} / \mathrm{P}$ ratio } \\
\hline & \multicolumn{4}{|c|}{ Group (1) } & \multicolumn{4}{|c|}{ Group (2) } & \multicolumn{4}{|c|}{ Group (3) } & \multicolumn{4}{|c|}{ Group (4) } & \multicolumn{4}{|c|}{ Group (6) } \\
\hline & $\sum_{\infty}$ & 㑇 & $\frac{p}{\dot{a}}$ & $\begin{array}{l}\vec{n} \\
\frac{a}{\infty}\end{array}$ & $\sum_{\infty}$ & $\stackrel{\mathscr{\mu}}{\underline{\theta}}$ & $\frac{m}{\dot{a}}$ & $\begin{array}{l}\vec{n} \\
\frac{\alpha}{a n}\end{array}$ & $\sum_{\infty}$ & 学 & $\stackrel{9}{\dot{1}}$ & $\begin{array}{l}\overrightarrow{0} \\
\frac{2}{x}\end{array}$ & $\sum_{\infty}^{0}$ & 㕷 & $\frac{m}{2}$ & $\begin{array}{l}\text { 党 } \\
\frac{1}{\infty}\end{array}$ & $\sum_{\infty}^{0}$ & 㕷 & $\frac{m}{\dot{a}}$ & $\underset{n}{0}$ \\
\hline Pre. & - & - & - & - & - & - & - & - & - & - & - & - & - & - & - & - & - & - & - & - \\
\hline 2 & 0.6 & 0.9 & 1.15 & 0.5 & 0.8 & 0.6 & 0.96 & 0.8 & 1.2 & 0.95 & 1.2 & 1.0 & 0.55 & 0.7 & 0.92 & 0.6 & - & - & - & - \\
\hline 3 & 1.6 & 1.8 & 1.6 & 1.2 & 1.5 & 1.8 & 1.4 & 1.5 & 1.8 & 2.1 & 1.6 & 1.7 & \begin{tabular}{|l|}
1.7 \\
\end{tabular} & 1.8 & 1.5 & 1.4 & - & - & - & - \\
\hline 4 & 2.0 & 1.9 & 2.2 & 2.1 & 1.8 & 1.9 & 2.0 & 1.7 & 2.4 & 2.2 & 2.5 & 2.1 & 1.85 & 2.0 & 2.4 & 1.8 & - & - & - & - \\
\hline 6 & 1.86 & 2.1 & 2.0 & 1.8 & 1.8 & 2.1 & 2.1 & 1.8 & 2.5 & 2.3 & 2.7 & 2.4 & 2.1 & 1.9 & 1.9 & 1.8 & - & - & - & - \\
\hline 8 & \begin{tabular}{|l|}
1.9 \\
\end{tabular} & 2.0 & 1.8 & 1.5 & 1.8 & 2.0 & 1.9 & 1.7 & 2.3 & 2.1 & 2.4 & 2.0 & 2.0 & 1.8 & 1.8 & 1.5 & - & - & - & - \\
\hline 12 & 1.8 & 1.8 & 1.6 & 1.5 & 1.5 & 1.8 & 1.8 & 1.5 & 2.0 & 1.9 & 2.1 & 1.85 & 1.8 & 1.55 & 1.8 & 1.4 & - & - & - & - \\
\hline 16 & 1.5 & 1.4 & 1.5 & 1.2 & 1.6 & 1.5 & 1.5 & 1.3 & 1.8 & 1.7 & 1.8 & 1.7 & 1.5 & 1.5 & 1.6 & 1.25 & - & - & - & - \\
\hline 20 & 1.45 & 1.4 & 1.35 & 1.3 & 1.2 & 1.2 & 1.2 & 1.25 & 1.5 & 1.5 & 1.56 & 1.5 & 1.4 & 1.2 & 1.2 & 1.1 & - & - & - & - \\
\hline 24 & 1.2 & 1.2 & 1.2 & 0.95 & 1.2 & 1.05 & 0.96 & 1.0 & 1.4 & 1.2 & 1.3 & 1.18 & 1.2 & 0.8 & 0.9 & 0.88 & - & - & - & - \\
\hline
\end{tabular}

Pre. Pre-vaccination

WPV Weeks Post Vaccination

Group (1): Sheep vaccinated with pneumo-4 vaccine only

Group (2): Sheep vaccinated with pneumo-4 and sheep pox vaccine simultaneously

Group (3): Sheep vaccinated with sheep pox, one week before vaccination with pneumo-4 vaccine

Group (4): Sheep vaccinated with sheep pox, one week after first dose of pneumo-4 vaccine

Group (6): Sheep unvaccinated control

Table (3): Serum sheep pox neutralizing index in vaccinated sheep.

\begin{tabular}{||c||c|c|c|c|c|}
\hline \multirow{2}{*}{$\begin{array}{c}\text { Weeks post } \\
\text { vaccination }\end{array}$} & \multicolumn{5}{|c|}{ Mean sheep pox neutralizing index } \\
\cline { 2 - 6 } & Group (2) & Group (3) & Group (4) & Group (5) & Group (6) \\
\hline \hline 0 & 0.15 & 0.15 & 0.15 & 0.15 & 0.15 \\
\hline 1 & 0.92 & 0.84 & 0.79 & 0.84 & 0.15 \\
\hline 2 & 1.28 & 1.30 & 1.23 & 1.20 & 0.15 \\
\hline 3 & 2.01 & 1.98 & 1.83 & 1.80 & 0.15 \\
\hline 4 & 2.26 & 2.20 & 2.08 & 2.11 & 0.15 \\
\hline 6 & 2.21 & 2.15 & 1.80 & 1.85 & 0.15 \\
\hline 8 & 2.09 & 2.00 & 1.67 & 1.67 & 0.15 \\
\hline 10 & 1.90 & 1.86 & 1.65 & 1.60 & 0.15 \\
\hline 12 & 1.71 & 1.80 & 1.55 & 1.53 & 0.15 \\
\hline 16 & 1.53 & 1.50 & 1.51 & 1.50 & 0.15 \\
\hline 20 & 1.49 & 1.50 & 1.46 & 1.46 & 0.15 \\
\hline 24 & 1.48 & 1.49 & 1.46 & 1.46 & 0.15 \\
\hline
\end{tabular}

Neutralizing index $(\mathrm{NI})>1.5$ is considered positive

Group (2): Sheep vaccinated with pneumo-4 and sheep pox vaccine simultaneously

Group (3): Sheep vaccinated with sheep pox, one week before vaccination with pneumo-4 vaccine

Group (4): Sheep vaccinated with sheep pox, one week after first dose of pneumo-4 vaccine

Group (5): Sheep vaccinated with sheep pox only

Group (6): Sheep unvaccinated control

Kafrelsheikh Vet. Med. J. Vol. 7 No. 1 (2009) 
Studies On The Effect Of Sheep Pox Vaccine On The Immune ...

Table (4): Mean ELISA (S/P ratio) in vaccinated sheep against sheep pox virus.

\begin{tabular}{||c||c|c|c|c|c||}
\hline \hline \multirow{2}{*}{$\begin{array}{c}\text { Weeks post } \\
\text { vaccination }\end{array}$} & \multicolumn{5}{|c|}{ S/P ratio } \\
\cline { 2 - 6 } & Group (2) & Group (3) & Group (4) & Group (5) & Group (6) \\
\hline \hline 0 & 0.31 & 0.25 & 0.28 & 0.33 & 0.26 \\
\hline 1 & 1.16 & 1.10 & 1.03 & 1.10 & 0.21 \\
\hline 2 & 1.25 & 1.22 & 1.15 & 1.19 & 0.22 \\
\hline 3 & 1.40 & 1.38 & 1.28 & 1.31 & 0.24 \\
\hline 4 & 1.62 & 1.57 & 1.53 & 1.52 & 0.27 \\
\hline 6 & 1.58 & 1.58 & 1.45 & 1.47 & 0.23 \\
\hline 8 & 1.54 & 1.45 & 1.43 & 1.40 & 0.21 \\
\hline 10 & 1.44 & 1.42 & 1.35 & 1.35 & 0.25 \\
\hline 12 & 1.35 & 1.37 & 1.32 & 1.30 & 0.27 \\
\hline 16 & 1.31 & 1.31 & 1.25 & 1.22 & 0.24 \\
\hline 20 & 1.22 & 1.20 & 1.16 & 1.14 & 0.25 \\
\hline 24 & 1.14 & 1.16 & 1.09 & 1.04 & 0.26 \\
\hline
\end{tabular}

ELISA reading $>1.0$ is considered protective

Group (2): Sheep vaccinated with pneumo-4 and sheep pox vaccine simultaneously

Group (3): Sheep vaccinated with sheep pox, one week before vaccination with pneumo-4 vaccine

Group (4): Sheep vaccinated with sheep pox, one week after first dose of pneumo-4 vaccine

Group (5): Sheep vaccinated with sheep pox only

Group (6): Sheep unvaccinated control

\section{DISCUSSION}

Sheep pox and respiratory viruses are major diseases affecting livestock and they have an adverse effect on their industry. In Egypt, the control of both diseases was conducted by vaccination with specific vaccines, which conferred a good degree of immunity against each one. Assessment of humoral immune response after vaccination is used for evaluation of the protective capacity of vaccines.

The developed specific antibody against BVD, IBR, PI-3 and BRV were detected on the $15^{\text {th }}$ day post vaccination (DPV). The obtained antibody titres appear to be higher than the minimal protective titre. This agrees with Mihajlovic et al. (1979) and Zuffa and Fedeteova (1980) who reported that the minimum accepted serum neutralizing titre was 0.6 
$\log _{10}$ or $1: 4$ against PI-3 and IBR, Bittle (1968) reported that the protective neutralizing antibody titre of BVD virus is $0.9 \log _{10}$ or $1: 8$ and Fulton et al.(1995) who mentioned that the serum neutralizing reciprocal titre 4 is considered a protective titre in vaccinated animal with modified live BRSV vaccine. The obtained titres remained high till 24 weeks (end of experiment) post vaccination with pneumo-4 vaccine. Also, the same results are obtained by using ELISA where the mean S/P ratio of ELISA against IBR, PI-3, BVD RSV viruses in sera of vaccinated sheep were protective and still high till the end of the experiment.

From the previous results, it is noticed that the titres of pneumo-4 antibodies in the group vaccinated with sheep pox vaccine, one week before the first dose of vaccination with pneumo-4 vaccine were higher than those in other groups and these results came in agreement with that reported by Abdel Samae et al. (1994) who concluded that sheep pox vaccine initiate the immune response of sheep when vaccinated by RVF vaccine 21 days after its vaccination by sheep pox vaccine.

On the other hand, sheep pox neutralizing antibodies were affected in different groups. It was represented in table (3), that the sheep pox neutralizing antibodies have the same levels with slight increase in group (2). They began to appear after one week post vaccination (WPV) (0.92, $0.84,0.79,0.94)$ in groups $2,3,4$ and 5 respectively, then increased gradually till reached the maximum titre on the $4^{\text {th }}$ WPV $(2.26,2.20$, $2.08,2.11)$ respectively, then decreased gradually till the $24^{\text {th }}$ WPV but still in the protective level $(\geq 1.5)$ as reported by (Cottral, 1978).

As shown in table (4), the results of ELISA revealed that SPV antibodies were appeared from the $1^{\text {st }}$ WPV as $1.16,1.10,1.03,1.10$ in groups $2,3,4$ and 5 respectively and reached their peak during the $4^{\text {th }}$ WPV $(1.62,1.57,1.53,1.31)$ in the same groups. 
These results proved that the presence of SPV with pneumo-4 did not affect the immune response of sheep against SPV but it was immunopotentiating the immune response of sheep against pneumo-4 viruses. This agreed with Samir et al. (1999) who proved the same conclusion with PPR vaccine.

Such results indicate that sheep pox virus vaccine acts as an immunostimulant agent, in agreement with Amina et al. (2001).

From the obtained results, it could be concluded that sheep pox vaccine initiates the immune response of sheep when administered one week before vaccination with pneumo-4 vaccine (IBR, PI-3, BVD and RSV).

\section{REFERENCES}

- Abdel Samae, M.; Khairat Elian and Gehan Kamel, M. (1994): The effect of RVF and sheep pox vaccines on the immune response of sheep. J. Egypt. Vet. Med. Assoc., 54 (2): 129-136.

- Abeer, E.M. (1996): Effect of using FMD vaccine in combination with other vaccines on the immune status of farm animals. M.v.Sci. Thesis, Infectious Diseases, Fac. Vet. Med., Cairo Univ.

- Amina A. El-Bayomy; Manal Awad; Safia T. Kandil; Soad M. Soliman and Michael, A. (2001): Immunological studies on sheep vaccinated with haemorrhagic septicaemia and sheep pox vaccines at the same time. J. Egypt. Vet. Med. Assoc., 61 (2): 385-393.

- Attia, H.; El-Sayed, R.F. and Hussein, I. El-Belbesi (1999): Laboratory and clinico-biochemical studies on respiratory affections in newborn calves. Alex. J. Vet. Sci., 15 (2): 195-204. 
- Baz, Thanaa, I.; Taha, M.M.; Zahran, M.H. and El-Dobeigy Aida (1986): Major respiratory viruses and multiple infectious in pneumoenteritis of newborn calves in Egypt. Vet. Sci., 23 (2): 235-248.

- Bittle, J.L. (1968): Vaccination for bovine viral diarrhoea - mucosa disease. J. Amer. Vet. Med. Assoc., 152 (6): 861-865.

- Carn, V.M.; Kitching, R.P.; Hammond, J.M. and Chand, P. (1994): Use of recombination antigen in an indirect ELISA for detecting bovine antibody to Capripox virus. J. Virol. Method, 49 (3): 285-294.

- Cottral, G.E. (1978): Pox Viruses. In Manual of standardized methods for veterinary microbiology. Ed. G.E. Cottral, Cornell Univ. Press (Ithaea and London), pp. 273-291.

- Durham, P.J.K. and Hassard, L.E. (1990): Prevalence of antibodies to IBR, PI-3, BRSV and BVD in cattle in Sakatchewan and Alberta. Cand. Vet. J., 31: 815-820.

- El-Dobeigy Aida, I.; Baz Thanaa, I.; Taha, M.M. and Saber, M.S. (1983): Incidence of bovine viral diarrhoea. Infectious bovine rhinotracheitis and parainfluenza-3 virus in Egypt. Agri. Res. Rev., 61 (7): 89-108.

- Fulton, R.W.; Confer, A.W.; Burge, L.J.; Perino, L.J.; D'Offay, J.M.; Paytom, M.E. and Mock, R.E. (1995): Antibody viral vaccines containing BHV, BVD, PI-3, BRSV immunogens and subsequent revaccination at day 140 . Vaccine, 13: 725-733.

- Hussein Metwally; Abdel Samae, M.M.; Magdi El-Sabbagh and Samira Said (1996): The effect of sheep pox and combined inactivated respiratory diseases vaccines on the immune response of calves. Beni-Suef Vet. Med. Res, VI (1): 47-55. 
- Knezevic, N.; Kosanovic, P. and Rogan, D. (1990): Immunoprophylaxis of respiratory diseases of cattle with inactivated vaccine. Study of the immunogenicity of a bivalent inactivated oil vaccine against IBR and PI-3. Veterinarski Glasnik, 44 (7): 503-512.

- Mihajlovic, B.; Cretkovic, A.; Ruznanovic, M.; Vuhobrat, D.; Assain, $R$. and Lazurevic, T. (1979): comparison of vaccines against respiratory disease of cattle rhinotracheitis and parainfluenza-3. veterinarski Olasrik, 33 (1): 33-38.

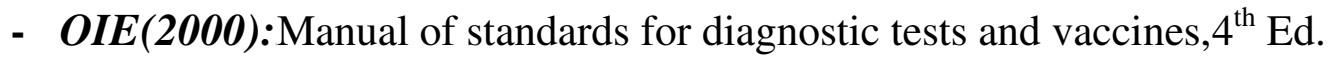

- Ozawa, Y. ad Hazrati, A. (1964): Growth of African horse sickness virus in monkey kidney cell cultures. Amer. J. Vet. Res., 25 (1051): 505-511.

- Reed, L.J. and Muench, H. (1938): A simple method of estimating fifty percent ed points. Amer. J. Hyg., 27: 493-497.

- Samir, S.S.; Wafaa A. Zaghloul; Saod M. Soliman; Nahed A. Kamel and Mouaz, M.A. (1999): Trials for vaccination of small ruminants using a combined PPR and sheep pox vaccine. Alex. J. Vet. Sci., 15 (4): 721-731.

- Taha, M.M.; Soad M. Soliman; Michael, A.; Wassel, M.S.; Monira I. Nassar and El-Debeigy, A.I. (1991): Studies on the immune response of sheep vaccinated with seep pox-RVF combined vaccine in comparison with each monovalent vaccine. Beni-Suef Vet. Med. Res. J., 1: 183-194.

- Zuffa, A. and Feketeova, N. (1980): Protective action of inactivated adjuvant IBR vaccine against experimental infection. Vet. Med., 25 (1): 51-61. 


\section{دراسة تأثير لقاح جدرى الأغنام على الاستجابة المناعية للأغنام المحصنة بلقاح النيهو ـ 4}

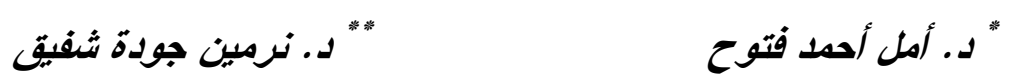

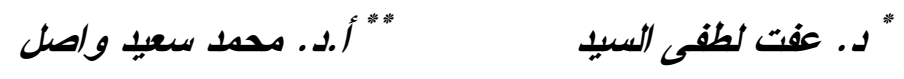

$$
\begin{aligned}
& \text { " معهل بحوث الأمصال و اللقاحات البيطرية - العباسية - القاهرة } \\
& \text { "* المعمل المركزى للرقابة على المستحضرات الحيوية البيطرية - العباسية - القاهرة }
\end{aligned}
$$

تم عمل دراسات فاعلية سيرولوجية لإسنتيان تأثثر لقاح جدرى الأغنام على المناعة الناتجة من تحصين الأغنام بلقاح النيمو -4 وذلك عند استخدامه تز امنياً وقبل وبعد التحصين.

تم إجر اء التجربة على عدد 18 خروف قابل للعدوى وقد نم تقسيمهم الى ستة مجموعات متساوية العدد حيث تم تحصين المجموعة الأولى بلقاح النيمو -4 والخامسة بلقاح جدرى الأغنام و استخدمت كضو ابط محصنة. وكنلك حقن لقاح جدى الأغنام مع لقاح النيمو -4 نزامنياً فى الى المجموعة الثانية بينما نم حقنه قبل التحصين بلقاح النيمو -4 (المجموعة الثالثة) بأسبوع وحقنه بعد التحصين بنفس اللقاح بعد أسبوع من الجرعة الأولى (المجموعة الر ابعة) وتركت المجموعة السادسة كضابط غير محصنة.

تم قياس المستوى المناعى المضاد للفيروسات المكونة لكلا اللقاحين باستخدام اختبار السيرم

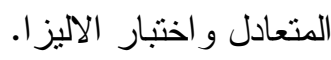

وقد أوضحت النتائج أن لقاح جدرى الأغنام عند حقنه قبل لقاح النيمو -4 باسبوع (المجموعة الثالثة) أعطى أعلى مستوى مناعى يليه المجموعتين الثانية والرابعة و التى حقتت تز امنياً وبعد التحصين باللقاح على الترتيب. وبذلك اوضحت الدراسة تأثير لقاح جدرى الأغنام المنشط للجهاز المناعى للأغنام خاصة عند استخدامه قبل التحصين باللقاح الآخر بأسبوع. 